\title{
Biblical Interpretation in the Russian Orthodox Church: An historical and hermeneutical perspective ${ }^{1}$
}

\author{
A Negrov ${ }^{2}$ \\ (University of Pretoria)
}

\section{ABSTRACT}

\section{Biblical Interpretation in the Russian Orthodox Church: A Histori- cal and Hermeneutical Perspective}

This study attempts to identify the issues that are specifically important for an understanding of biblical interpretation within the Russian Orthodox Church. Its purpose is not to advocate pro or contra Russian biblical scholarship, but to place the emphasis on the history of biblical interpretation in the Russian Orthodox Church and on Orthodox biblical hermeneutics. Two considerations are specifically pertinent to the study of this topic. First, the history of biblical interpretation is surveyed from a sole and specific perspective - from within a historico-dogmatic development of the Russian Orthodox Church from the Kiev period of its history (9-13 $3^{\text {th }}$ century) till the Synodal period (1721-1917). Second, it is true that once originated, the Biblical Study in Russian Orthodoxy went its own way and developed its own fundamental principles of interpretation. Although many principles correlated and corresponded with general principles of biblical interpretation, in essence they form "Russian Orthodox Hermeneutics". This paper seeks to establish an outline of the essential elements of Orthodox biblical hermeneutics as they developed in the history of interpretation.

\section{A HISTORICAL PERSPECTIVE}

Before we speak of the Orthodox hermeneutical position I would like to outline the historical trends of bible interpretation in the Russian Church.

\subsection{Historical Beginning: Kievan Period $\left(10\right.$ th $-13^{\text {th }}$ century)}

Soon after the beginnings of Russian Christianity, following the Baptism of Russia in 988, the handwritten editions of the biblical books became known in Kievan Rus'. The reading of the Bible, during the initial period

\footnotetext{
${ }^{1}$ A short version of this article was presented at the Society of Biblical Literature 2000 International Meeting on July $28^{\text {th }}, 2000$ in Cape Town, South Africa.

${ }^{2}$ This article is a summary of a doctoral thesis by Alexander Negrov under the supervision of Prof J G van der Watt, Department of New Testament, University of Pretoria.
} 
of the Russian Church, was, certainly, not contemplated from the point of view of theoretical knowledge. An appeal to the study of biblical literature was delayed due to the following circumstances: (1) the majority of the Orthodox clergy were illiterate; (2) the church used the variety of religious literary sources for edification; thus the Bible was not a distinct object of interest, reading and study; (3) since the Byzantine brought the Bible into Russia, together with its pre-formed understanding, (Birnbaum 1984:3-30) ${ }^{3}$ for the young Russian Church it seemed there was nothing left to develop; and (4) for the Russian people of this period, "it was easier to express their thoughts and feelings through music, color, and design than through books and learned discourses" (Zernov 1998:5).

The period, however, influenced the long-term outlook of the Orthodox biblical interpretation in two ways. First, the writings of the Greek Church Fathers introduced the Russian readers to the variety of interpretative approaches to the Bible. Second, since the biblical literature was received widely and with a prevalent veneration as "books of the Church, rather than of the individuals" (Sol'skii 1868:168), an ecclesiastical ideology and culture initiated a communal authority over the biblical tradition of faith.

\subsection{The period of Tartar invasion (1280-1480)}

In 1240 the Mongol invasion isolated Russia from Europe. This isolation lasted for many centuries. Nevertheless, due to many factors there has been a transmission of enlightenment from the cultured South to the North-East of Russia (cf. Florovsky 1937:9). The number of the learned increased.

The entire period of Tartar invasion is marked by the concern of the Russian thinkers for a proper reading of all the religious literature. As a result, short instructions on how to read the sacred books were composed. For illustration, all the versions of the Izmaragd - a very popular collection of poetry, legends and traditions (created by unknown compilers) in Ancient Russia begin with a group of articles on "divine books". In these instructions, the prayer for illumination is suggested as a key for understanding. In addition, a specific standard is attached to the integrity of the readers. The readers must be holy, because "the holy men have the reason given by God; and in having books, they do not pervert them by following after their own minds" (in Materiali quoted by Fedorov 1966: 46). A "holy" reader would not misinterpret the text, but would mirror the set of established truths, which served as the hermeneutical basis.

${ }^{3}$ Cf Bimbaum (1984:3-30). The influence of Byzantine Empire on the Russian Orthodoxy is discussed, among others, in: Dvornik (1962); Meyendorff (1982); Obolensky (1982). 
This formulates a hermeneutical assertion: religious submission and the moral quality of the readers have an affect on the process and results of understanding. Unfortunately, the elementary approach, suggested in the above named instructions, fails to show concern for the question how to fit the Bible into the categories of understanding.

Besides, soon a spirit of reading the biblical literature was carried away by the interest toward the mystical and ascetic texts. The hunger for the ecclesiastical independence from Constantinople had also distracted the Russian Orthodox thinkers from the task of bible interpretation.

\subsection{The period of ecclesiastic self-establishment (15-18 ${ }^{\text {th }}$ century)}

In 1448 the Russian Church became independent from the Patriarchate of Constantinople, with its new center in Moscow. Reasoning that the Russian faith is Christian, but not Greek, the Russian Orthodox Church dismissed Greek as the liturgical language. Consequently, soon she found herself linguistically disjointed from the language of the New Testament and the Greek Church Fathers. The importance of Russian as the liturgical language, and the appearance of the Russian heretical movements of so-called Strigol'niki (Eng - "shorn-heads") and Judaizers (Ru.zhidovstvuiushchie) (see Klibanov 1960) stimulated the appearance of a new Slavonic translation of the Bible. ${ }^{4}$ The Church's clergymen were inclined to think that the heresies and doubts began precisely "through the reading and misinterpretation of biblical texts" (Florovsky 1937:14). Thus, a proper understanding of the biblical literature became, for the first time, ideologically significant. In an attempt to discover such understanding, the Church appealed to the writings of the Church Fathers. (Since then, the Russian Orthodox Church has traditionally used the Patristics as "a dogmatic-doctrinal guide, which regulates the freedom of theological creativeness" - Glubokovskii 1928:38).

During the 17th century, known for the so-called Raskol (schism), the variety of concerns over the question of the religious future of Russia created political and ecclesiastical controversies that preoccupied the minds of the Orthodox clergy. For more than a century the Orthodox theologians and teachers of the Bible were preoccupied with defending or overcoming new-old-and -non orthodox doctrines. Only a small number of expository commentaries were composed. These studies, in nearly all their arguments, relied heavily on Latin and German sources. Often, the ideas and conclusions of others were presented as their own (cf. Florovsky, 1979:354; Men' 1987:275). The retelling, or even direct translating, from the Western theological literature became a habit of many Orthodox writers during this and following periods.

4 Completed in 1499 it is known as Gennadievskaia Bibliia, after Archbishop Gennady of Novgorod (1484-1504). 
Nevertheless, a prolonged appeal to the patristic literature, the origin and development of the theological education during the 17-18th centuries, called forth a start to a structured study of the Bible. In addition, the labour of bible translation produced people that were potentially able to study Scripture on a more sufficient and erudite level. Among those who made a first stimulus to a systematic bible interpretation were the lecturers of Moscow Orthodox Academy - Macari Petrovich (d. 1766), Feofilakt Gorsky (d. 1788), Tikhon Malinin (d. 1798) and Gavriil Petrov (d. 1801) Their positive influence is seen in the accomplishments of their pupil - the Metropolitan of Moscow. Platon (Levshin, 17371812). ${ }^{5}$

The Orthodox theological education is obliged to Platon for fixing its orientation toward the historical inquiry. Under his administration, in 1786, the systematic exegesis of Scripture, oriented on "the best Church teachers-exegetes" was offered to the students of the Moscow Academy. At the same time, in order to benefit an accurate interpretation of the Holy Scriptures, the Holy Synod introduced the discipline biblical hermeneutics in all the Orthodox schools. This should be considered as the origin of the biblical studies in the Russian Orthodox Church.

In 1776, Platon formulated the principles of bible interpretation and presented them as obligatory to the Faculty of Moscow Theological Academy (Platon 1913:691). He encouraged the interpreters of the Bible: (1) to search for the literal and historical meaning of the biblical texts, because the Scriptures should be understood in connection to the time and place of their authors; (2) to understand the Scriptures literally without searching for a mysterious unattainable meaning; (3) to be orientated on the works of patristic heritage as warrant of right interpretation; (4) to pray for the illumination of the Holy Spirit who can "open the eyes for understanding" (Platon 1913:691); (5) to consider the Bible as capable of explaining itself when the biblical books are taken in their totality and correlation. Platon's rules might be considered as an important step towards the establishment of the Russian Orthodox hermeneutics.

Platon's associates took his work further. Among them was Professor Andrei Podobedov (1742-1818, later the Metropolitan of St. Petersburg), who in 1799 published the first Russian Orthodox textbook on the questions of introduction (Podobedov 1799). In 1808, the Archbishop Feoktist Mochulsky, (1832-1818) published the first ever textbook on Biblical Hermeneutics. Bearing this in mind it can be concluded that the question of how to interpret biblical literature had been raised in the $18^{\text {th }}$ century. The answer, however, had not yet been discovered. Displaying the faithfulness to the Orthodox Church and to the writings of the Church Fathers, the paraphrases of the Church Fathers commentaries

${ }^{5}$ See Snigirev (1857); Barsov (1891); \& Papnehl (1983). 
still prevailed over the point-by-point interpretation of the biblical texts (cf Mikhail 1889:124-125).

\subsection{Creation of the Orthodox theological consciousness in the $19^{\text {th }}$ century Russia}

From about 1820 a new spirit of inquiry was clearly discernable in Russia. The Orthodox exegetes became aware of the critical methods of historical and literary scholarship that had developed in the West (see the standard books). They also witnessed the religious philosophical awakening in Russia (see Berdyaev 1946, Lossky 1991, Zen'kovskii 1953-67). The intellectual mentality of the $19^{\text {th }}$ century provided for the Orthodox biblical interpretation: (1) a basis for theorizing; (2) the prospect of interdisciplinary studies; and (3) an openness for new solutions.

There was a motion towards a careful study of the Bible in the early $19^{\text {th }}$ century. Among the labourers in the field were: the Metropolitan of Moscow, Filaret (Vasily Drozdov, 1783-1867); archbishop Alexander M. Bucharev (1822-1871); and archbishop Gerasim Pavsky (1787-1863). These are identified as "the true founders of the Russian Orthodox study of the Bible" (Men' 1987:274). Filaret stressed the importance of linguistic expertise in exegesis, and advocated a historical investigation of the biblical literature. Also, for the first time in the Orthodox exegetical practice, he connected its methodology with church doctrine. On the contrary, Aleksandr Bukharev was not interested in the historicity of the Bible. He stressed the imaginative, mystical interpretation of "strictly spiritual texts" (Bukharev 1916:9). In his opinion, the practice of a mystical exposition of the text should be preferred over the historicogrammatical investigation and even dogmatic interpretation (see Znamenskii 1892:185). Gerasim Pavskii was the first Russian exegete to point out the wide range of genres in biblical literature, and stressed their importance in the process of interpretation. Pavskii underscored a scholarly engagement with the text - not only a systematic study of ancient history, grammar, meanings of the words, purpose of the passage etcetera, but also the inquiry into the critical problems of the authorship and sources. His writings were the first in the Russian Orthodox Church to question the authenticity of biblical books.

Despite the innovative works of the above-mentioned exegetes, the development of the field of biblical studies in early $19^{\text {th }}$ century was insignificant (cf. Mikhail 1878; Sol'skii 1868:814). The deficit of further advancement was caused by: (1) a superficial theological training; (2) a period of prohibition of Bible interpretation, except when the intentions of interpretation were examined by the church authorities (see Chistovish 1879:338); (3) the placement of the Bible as secondary to the church tradition; and (4) the church censorship (cf. Mikhail 1878:33; Innuarii 1986:193). 
After a new Academic Constitution was accepted by the Holy Synod (on May 30, 1869), the Orthodox schools were obliged to create faculties in Biblical studies (Eleonskii 1901:637). In 1876, a new Russian translation of the Bible [known as Synodal Bible] was published. All this brought about an era of enthusiasm in the field of bible interpretation. By employing a thorough selection of the authors and their studies, it is possible to outline the developmental process in several specific areas of Biblical Studies: (1) biblical hermeneutics; (2) questions related to the introduction; and (3) the exegetical works.

\subsection{Biblical hermeneutics}

In the $19^{\text {th }}$ century, the Orthodox scholars saw hermeneutics as the formulation of rules for the understanding of an ancient text, especially in linguistic and historical terms (contra western theological development, where hermeneutics already tended to include philosophical and psychological theories of meaning and understanding). Prof. Pavel Savvaitov (1815-1895), in his Biblical Hermeneutics, advocated that special attention should be paid to "the harmony (soglasie) with the rule of faith" (Savvaitov1859:110). He laid emphasis on the binding role of the church tradition and the legislative authority of the church in establishing a final statement of the theological truth of the Bible. In 1891, Fr. Arch. Antonii (Khrapovizkii, d.1936) published a book of a fourth century Donatist theologian and exegete, Tyconius of Africa (d. in about 391). Fr. Antonii wrote an Introduction to this book, in which he outlined his hermeneutical theory (Antonii 1891:1-22). Its main arguments conveyed: (1) the notion of an energizing God-revealing force in understanding the Bible (pneumatology is emphasised); (2) the consideration of God-enclosed figures of speech and symbols in the text; (3) the self-explanatory nature of the Bible; and (4) the controlling factor of the pronema ekklesias. In his monograph, A New Testament Interpretation of the Old Testament, Prof. Ivan Korsunskii (1849-1899) distinguished typology as the most appropriate method of Orthodox exegesis (Korsunskii 1885). Korsunskii stressed the continuity and harmony between the biblical testaments, and saw Christ as the center and focus of biblical interpretation.

\subsection{The question of introduction}

An attempt to give answers to the introductory issues of the Bible formed a specific corpus of the Orthodox-biblical literature, known elsewhere as "Introductions" (esp. in German biblical scholarship). The short lectures on The Introduction to the New Testament by Prof. V. Roshchdestvenskii served as a starting point that modeled a basic approach to the problem for the succeeding Orthodox scholars (Roshchdestvenskii $1877-78)$. He took the scope of introductory questions from 
western biblical literature and critically responded to the main points of disagreement. In 1892 Mitr. of Moscow Filaret, in his Introduction to the New Testament, postulated that the study of the background should not lead to conclusions that contradict the church dogma (Filaret 1882:1-8). From this moment on, the Orthodox interpretators welcomed only the questions on background, purpose and general teaching of the biblical literature. The inquiry into the issues of authorship, dates and the problems of origin or literary composition of biblical writings was rejected as an extra-theological analysis.

\subsection{The exegetical works}

Although the first fruits of Russian Orthodox exegesis appeared in $18^{\text {th }}$ century, the period of the greatest productivity of exegetical works took place during the course of the second half of the $19^{\text {th }}$ century to the beginning of the $20^{\text {th }}$ century. The studies written during this period indicated that the Orthodox exegesis applied the use of numerous methodological steps and the use of the different areas of knowledge (such as biblical history, archaeology, biblical languages, etc). It was seen as vital to study the biblical texts in their original languages. Attention was also given to the literary and historical contexts, the comparative study of the Gospels, and the character of authorial corpus and style (cf. Sol'skii 1866: 157-190; Sol'skii 1868: 251-270).

Mitrofan Muretov (1850-1917) was one of the most prominent exegetes of this period. Two main characteristics of his exegesis stand out in his published studies (esp. Muretov 1915). First, it is a Christ-centered exegesis. In his view the Bible should only be explained and studied through Christ. Consequently, exegesis should be mainly of theological concerns. Second, Muretov's exegesis is of the historical kind. Here a point is made for the historical reliability of Scripture. He assumed that the Bible is concrete history, and at the same time has super historical significance. This underlines the distinctive characteristic of the Orthodox exegesis as at once historical and meta-historical.

\subsection{The developments after 1917}

When the Bolsheviks came to power in 1917 the Russian Orthodox Church became an ideological enemy a priori. Many bishops, thousands of clergymen as well as lay people, were subjected to repression including execution. The theological schools were closed. The best Orthodox scholars emigrated from the country.

During most of the Soviet era religious expression was strictly discouraged. The Communist Party controlled religious institutions. The state imposed severe restrictions on religious activity, including the professional study of the Bible. 
The recent theological conference of the Russian Orthodox Church 'An Orthodoxy on the Threshold of the New Millennium', which was held in Moscow (7-9 February, 2000), evaluated the Orthodox theology in the XX c. It recognised that after the Bolshevik revolution of 1917, the field of biblical interpretation was nearly fruitless (esp. Innuarii 2000). The recent developments, which occurred after the dissolution of the USSR in 1991 are the subject of future analysis.

\section{A HERMENEUTICAL PERSPECTIVE}

With the historical overview in mind, we may now specify the main features of "Russian Orthodox Hermeneutics".

\subsection{The Patristic Feature}

Without doubt, the nature and characteristic of Russian Orthodox biblical interpretation and exegesis is deeply influenced by patristic exegesis. ${ }^{6}$ The patristic concept of interpretation is assigned to be "the first and the most important principle" of the Russian Orthodox biblical interpretation (Men' 1987:272).

This orientation is dictated by the following factors. First, the patristic writings and interpretative methodology indisputably support the authority and significance of the Bible as the communicated Word of God for the church and society (see Sol'skii 1866). Second, the Church Fathers' works, pertaining to biblical exposition and interpretation, establish and maintain the most important issues for the Orthodox tradition, teaching and dogma. Third, the patristic approaches to Scripture, and the practice of "typological", "allegorical" and "spiritual" exegesis is appealing to the Russian Orthodox exegetes. Fourth, the Church Fathers established a pattern of Bible interpretation, in which a Christocentric emphasis and the idea of an unbroken and organic unity between the Old and New Testaments are interrelated.

The faithfulness to patristic hermeneutics, argues the Orthodox theologian and historian Lev Karsavin (1882-1952), does not limit free investigation of the Bible; it is rather a source of inspiration of the biblical interpretation (Karsavin 1926).

\subsection{The relationships between Scripture, Church and Dogma}

In the determinations of the Russian Orthodox Church, the principle of the authority of ecclesiastical understanding is an important key to unlocking the meaning of biblical texts. Nikol'skii speaks for everyone: "In our Church we have, like in the treasury, all the authentic foundations

\footnotetext{
${ }^{6}$ Especially by St. Gregory of Nazianzus (circa 329-89), St. Athanasius (circa 293373) Clement of Alexandria (150?-215?), St. Basil, called Basil the Great, (circa 329-379) and St. John Chrysostom (354?-407).
} 
for interpreting the Word of God" (1875:188). It means that the Russian Orthodox interpretation of the Bible is ecclesiastical. Assuming that the church is always right, sinless and significant (cf. Antonii 1862:12), Vladimir Ribinckii (1902:382) stresses that "the Church is the best interpreter of the spirit and meaning of the Bible". In this mode of thought, the church becomes the highest reality prior to Scripture and it is a final authority of Bible interpretation. The notion that a true understanding of the Bible is stored in the church implies a hermeneutical feature of "the faithfulness to the spirit of the Church" (Mikhail 1889:125). All the inquiries of a scientific or exegetical kind, then, presuppose that Scripture and church could not be separated or be opposed to each other.

The church is a priori in reading the Bible, because many books of the Bible (the entire New Testament) "were authored for an already existing Church" (Illarion 1914:16-18). For this reason it is understood that Scripture was given to the church as to its interpretative community. The church is not an external authority, which has to judge over the Scripture. Rather, she is the keeper and guardian of that Divine truth which was stored and deposited in the Bible. It is assumed that only in the Russian Church, within the community of a rightful Orthodox faith, could the Scriptures be adequately understood and interpreted correctly. Archbishop Illarion (Troizkii, d. 1929) underscores this point: "only for a man who belongs to the Church is it conceivable to receive an accurate message of the Holy Scriptures" (Illarion 1914:17).

An entire dogmatic premise is a quintessential criterion for the interpreter to bring forward unanimity of a scientific investigation of the Bible and faithfulness of the church. Whatever is opposed to the dogmatic truths of the church - the whole pronema ekklesias (the mind of the church) must be set aside. In the words of Fr. Serguis Bulgakov (18711944), an ecclesiastic principle of the interpretation establishes the exegesis as being dogmatically pre-conditioned (1965:59).

\subsection{Tradition of the Church}

The Russian Orthodox hermeneutics is grounded in the persuasion that "the Apostolic and Church Tradition of the Orthodox faith is the indispensable guide to the understanding of Scripture and the ultimate warrant of right interpretation" (Florovsky 1972:77). The tradition is not an independent instance or complementary source of faith, but it is a living experience of the whole church. It derives from the consciousness of all departed and living Orthodox people who preserved the truth, and also contributed to the stream of the Orthodox faith in which the church stands. The Holy Spirit, bestowed on the church at Pentecost, is seen as the guide of the church "in all truth" (John 16:13). Thus, it is not the person or a group of individuals, but the Spirit of God, dwelling in the church, which continually preserves and "writes" the church tradition. 
Both tradition and Scripture launch and precisely express the Orthodox theology (Antonii 1862:6). Because of the ambiguity of many biblical texts, "the tradition helps to find out a correct cognition of the Scripture" (Grigorii 1914:94). The tradition is important to the Orthodox exegetes, because it frames the understanding of the Bible and perfects any spiritual or scientific channels for receiving the Words of God (cf. Evdokimov 1949: 152-154).

\subsection{The nature of revelation, inspiration and authority of the Bible}

The Russian Orthodox Church defines every doctrine as revealed by God. The revelation is disclosed to the whole church of all ages. The church holds the revelation of God, faithfully preserves it, and transmits it from one generation to the next. The significant written sources that contain God's revelation and construct the doctrines are: (1) The Holy Scriptures (Old and New Testaments); (2) the works of the Church Fathers; and (3) the constitutions of the Church Councils. Although God's revelation of truth is not limited to the Bible, the Bible still is of a prima status because it was "originally written under the inspiration of the Holy Spirit" (Antonii 1862:6). The Bible "is the main source of the Church's teaching; and, a living, fundamental understanding of the dogmas is impossible without its completed knowledge" (Nikol'skii 1875:186). The church is also accountable to the Scriptures, and yet, "the authority of the Scripture rests on the judgment of the Church" (Men' 1987:274).

The inspiration of the Holy Scripture means that "everything that the biblical writers recorded [in it] was recorded as a result of a direct enlivening of the Holy Spirit; hence, being guarded from misconception, the writers received the thoughts and words without intimidation of their natural abilities" (Antonii 1862:6) to arrange and express biblical material. Both the divine and human nature of the Bible are recognised in the church. Yet, the concept of inspiration of the Bible is not based in or fixed by any given text or book (or the entire Bible), but it is inborn in the revelation, which belongs to the church, the revelation of the Holy Spirit that dwells in the church.

\subsection{The Christological basis of biblical interpretation}

Orthodox scholars point out that, if the divinity of Jesus and his supernatural deeds are not accepted, then study of the Bible becomes incomplete and violated by an interior imperfection concerning the whole Bible - the fullness of their revelation of Christ. Thus, the interpretation of the Bible is interrelated with the understanding of Christ. From this presupposition it is assumed that the fulfillment of the Old Testament and the fullness of historical revelation is Christ - the chief and main 
subject of Scripture. Therefore, Christ is the beginning, center, and end of biblical interpretation. Christ is the hermeneutical key to Scripture.

\subsection{The role of the Holy Spirit in understanding the Scripture}

The Bible for the Orthodox is the collection of books "originally written under the inspiration of the Holy Spirit and therefore are called Godbreathed" (Antonii 1862:6). It means that the Bible has its origin in God himself, and that the Bible is God's Word, communicated to the people by his Spirit. Because the Holy Spirit is involved, the formation of the Bible is of "a religious-symbolical nature, i.e. it has a religious reality" (Bulgakov 1994:85). This reality may not be clear for an unreligious scientific investigator. Rather, it is revealed only to the illuminated religious readers of the Bible. The Holy Spirit, working in the church, is an illuminating agent that enables a human reader to comprehend the sacred Bible properly. The Spirit also restricts the individualistic impulses of an interpreter, thus avoiding misconceptions. Exegesis, then, is a divinehuman enterprise based upon synergy or cooperation between the divine Spirit and the human interpreter. The interpretation of the Bible is possible in the sense of a synthesis of the human creative efforts enabled by the Holy Spirit dwelling in the church. Thus, the exegete must submit himself and his skills to the guiding influence of the Holy Spirit, if his efforts are to bear fruit for the body of Christ. A scholar who uses scientific methods of any kind, without the Holy Spirit, is bound to discover only the meaning that is close to or on the outer surface of Scripture (Nikol'skii 1875:190).

\subsection{The actualization of the Scripture in personal and corporate \\ life}

The Russian Orthodox hermeneutical theory presupposes complex corporate interrelated dimensions of the church tradition and mystical self-involving experience. This becomes more evident in the assessment of the anthropological concept of wholeness of men as the existential hermeneutical principle. For the Russian Orthodox Bible interpretation, the individuality or self-sufficiency of an exegete is excluded. The guidance in theology cannot be derived from the authority of any particular expert, or from a selected group of exegetes by reason of their nature being inaccurate. Such guidance is possible and essential only if "it is concluded in the harmony and agreement of all Christian pastors and teachers" (Antonii 1862:11). Therefore, the Orthodox scholar cannot begin his work by taking himself as departure, but always working within the Orthodox community - the unity of the Orthodox worship, liturgy, scholarship, preaching, sacraments and prayer. Because "the universal spirit of the Orthodox Church preserves the interpreter of the 
Bible from needless individualistic mysticism and heretical misunderstanding" (Evdokimov 1949:152), the corporate element has a critical role as the interpretative context.

\subsection{A scope of the historico-grammatical interpretation}

The Russian Orthodox Church recognises both the divine and human nature of the Bible. The human authors arranged and expressed biblical material in correspondence to their language-individuality-context situation (cf. Antonii 1862:6; Bulgakov 1947:63). Therefore, she welcomes the universal rules of literary and historical research as applicable to the biblical books.

The Russian orthodox hermeneutics stresses that if an interpreter wishes to fully understand the biblical writer, he must be guided by the following criteria of the author's meaning: his language; his train of thought; the context; and his psychological and historical condition at the time of writing. Thus, one might find the sense of a book by way of its language (grammatically - philologically), and by way of the writer's mental and external condition (psychologically and historically). Expressing the same truth negatively, it could be said that any meaning of a passage which does not agree with its grammar, its context, and the internal and external conditions of its author, cannot be accepted as the true sense. Yet, above all, any meaning, not keeping with the spirit of the church's interpretation and tradition, cannot bear the true sense of Scripture.

The final word on the history of biblical interpretation in Russian Orthodox Church is a perplexing task. Its analysis evokes careful thought and requires continuing investigation. Fr. Mikhail (Luzin) states well: "for a simply curious mind and more for the mind longing for a serious study, the observation of Biblical studies in Russia presents many things that make one think, rejoice and sorrow, meditate and search" (1889:115116).

\section{Consulted Literature ${ }^{7}$}

Antonii (Khrapovizkii), 1862. Dogmatic Theology. $8^{\text {th }}$ ed. Saint Petersburg. (Ru.) -, 1891. "Concerning the Rules of Tichonii of Africa: Their Validity for a Contemporary Exegesis in Tyconius of Africa, The book about seven rules for investigation and determination of the meaning of a Sacred Bible. Trans. into Russian from Latin Liber de septem regulis ad investigandam at inveniendam S. Scripturae intelligentiam in Patrologiae cursus competus (Lugduni, 1677). Moscow: Volchaninova Press, 1-22 (Ru.).

\footnotetext{
${ }^{7}$ Abbreviation (Ru.) will be used for the literature in Russian.
} 
Barsov, A 1891. Biography of Mitr. Platon, Moscow (Ru).

Berdyaev, N 1946. Russian Idea. Paris (Ru.).

Birnbaum, H 1984. "The Balkan Slavic Component of Medieval Russian Culture", in H Birnbaum \& M 1 S Flier, Medieval Russian Culture, Berkeley, 3-30.

Bulgakov, S 1947. The Orthodoxy. Paris (Ru.).

-, 1994. The Unfading Light. Moscow: Resbublica (Ru.).

Bukharev, A (Arch. Feodor) 1916. Investigation of the Apocalypse. Moscow: Sergiev Pasad (Ru.)

Chistovich, I 1879. The Leading Figures of Religious Education in Russia. Saint Petersburg (Ru.).

Dvornik, F 1962. The Slavs in European History and Civilization, Rutgars University Press.

Eleonskii, F 1901. The Russian Indigenous Works of Biblical studies in XIX c. Christian Reading. I, 633-660.

Evdokimov, P 1949. An Eastern Orthodox Bible Study. Student World XLII/12, 152-154.

Fedotov, G 1966. The Russian Religious Mind. Vol. 2: The Middle Ages - XIII-XV cc. John Meyendorff, ed. Cambridge, MA: Harvard University Press, 1966.

Filaret (Mitr. of Moscow), 1882. Introduction to the New Testament. Joy of the Christian in Reading the Bible. Feb., 1-8 (Ru.).

Florovsky, G 1937. The Ways of Russian Theology. Paris (Ru.).

-, 1972. Bible, Church, Tradition: an Eastern Orthodox View. Collected Works of George Florovsky - Volume I. Belmont, Mass.: Nordland.

-, 1979. Ways of Russian Theology: Part One. Gen. ed. Richard D. Hauch. Belmont, Mass. Nordland, 1979.

Glubokovskii, N 1928. Russian Theological Discipline in its Historical Development and Present State. Warsaw: Synodal Press (Ru.).

Grigorii, 1914. Sacred Tradition is not less than Sacred Scripture. A Useful Reading for Soul. III, 9, 94-97 (Ru.).

Illarion (Troitskii), 1914. Sacred Scripture and the Church. Moscow (Ru.).

Innuarii (Ivliev), 1986. Contribution of St. Petersburg Ecclesiastic Academy for the Russian Biblical Scholarship. A Jubilee Edition of Theological Works, 192-198

-, 2000. Biblical Studies in the Russian Orthodox Church in XX .c. Unpublished paper presented at the Conference "An Orthodoxy on the Threshold of the New Millennium'. Moscow (7-9 February, 2000) (Ru.).

Karsavin, L 1926. Sts. Fathers and Teachers of the Church. Paris (Ru.).

Klibanov, A 1960. The Reformation Movements in Russia (XIV -XVI cc.) Moscow: Nauka (Ru.).

Korsunskii, I 1885. A New Testament Interpretation of the Old Testament. Moscow (Ru.)

Losskii, N 1991. The History of Russian Philosophy. Moscow (Ru.).

Men', A 1987. Toward the History of Russian Orthodox Biblicism. Theological Works \#28 (Ru.).

Meyendorff, J 1982. The Byzantine Legacy in the Orthodox Church, Crestwood: St. Vladimir's Press.

Mikhail (Luzin) 1878. A Century of Bible Interpretation in Russia. Moscow (Ru.). -, 1889. Biblical Science. Vol. 1 Tula: Fortunatov Press (Ru.).

Muretov, M. 1915. The New Testament as the Subject of the Orthodox-Theological Study. Moscow: Sergiev Pasad (Ru).

Nikol'skii, N 1875. Our Biblical Science. Orthodox Review 1, 184-196 (Ru.). 
Obolensky, D 1982. The Byzantine Inheritance of Eastern Europe. London: Variorum.

Papnehl, K L 1983. Metrapolitan Platon of Moscow, Newtonville, Mass.: Oriental Research Partners.

Platon (Levshin), 1913. Polnoe Sochinenie [The Complete Works] 2 Vols., St. Petersburg: Soikina (Ru.).

Podobedov, A 1799. Guide to Study the Sacred Scriptures of the Old and New Testaments (Saint Petersburg (Ru.).

Ribinckii, V 1902. About the Bible. Works of the Kiev Ecclesiastical Academy. 3, 359-382 (Ru.).

Roshchdestvenskii, V 1877-78. Historical Overview of the Sacred Books of the New Testament. Works of the Kiev Ecclesiastical Academy (Ru.).

Snigirev, I 1857. The Life of Moscow Mitr. Platon, Moscow.

Savvaitov P 1859. Biblical Hermeneutics. Saint Petersburg: Treia (Ru.).

Sol'skii, S 1866. A Short Review of the History of Biblical Exegesis. Works of the Kiev Ecclesiastical Academy 10, 157-190; 11, 305-320; 12, 466-506 (Ru.).

-, 1868. The Use and Study of the Bible in Russia. Orthodox Review 10, 145-189; 11, 251-270 (Ru.).

-, 1869. Review of Biblical Scholarship in Russia from the XV c. Orthodox Review 2, 190-221; 4, 538-577; 6, 797-822 (Ru.).

Zernov, N 1998. The Russians and Their Church. $3^{\text {rd }}$ ed. Crestwood: SVS Press.

Zen'kovskii, V 1953-67. A History of Russian Philosoph.y. 2 Vols. Eng. trans. by George Kliene, London: Routledge \& Kegan.

Znamenskii, P. The History of Kazan' Ecclesiastic Academy: Part I. Kazan': University of Kazan'(Ru.). 